\title{
Soil residual activity and plant-back periods for the herbicides saflufenacil and topramezone
}

\author{
A. Rahman, C.A. Dowsett, M.R. Trolove and T.K. James \\ AgResearch, Ruakura Research Centre, Private Bag 3123, Hamilton 3240, New Zealand \\ Corresponding author: anis.rahman@agresearch.co.nz
}

\begin{abstract}
To quantify soil residual activity and plant-back periods for two maize herbicides, saflufenacil and topramezone, different rates were applied to a cultivated soil and samples $(0-5 \mathrm{~cm})$ collected at regular intervals for glasshouse bioassays. Phytotoxic residues of saflufenacil applied at $17 \mathrm{~g}$ ai/ha, the rate used for conservation tillage and pasture renovation, persisted in the soil for $<2$ weeks for the susceptible species, viz. white clover, onion, carrot and radish. Residual activity from $102 \mathrm{~g}$ ai/ha, the rate recommended for maize, dissipated within 4 weeks for all species. Wheat, ryegrass, carrot, squash, onions and tomato were not affected by topramezone residues from rates up to $202 \mathrm{~g}$ ai/ha in soil collected 2 weeks after treatment (WAT). However, peas, white clover and radish all suffered damage in samples collected 2 WAT. By 4 WAT, only white clover and peas exhibited minor phytotoxicity.
\end{abstract}

Keywords saflufenacil, Sharpen, topramezone, Arietta, residual activity, plant-back, persistence, maize.

\section{INTRODUCTION}

Two herbicides, saflufenacil and topramezone, were recently registered for weed control in New Zealand maize and sweet corn crops. Saflufenacil applied pre-emergence, in combination with acetochlor, provides good control of annual grass and broadleaf weeds (Trolove et al. 2011), while topramezone, tank mixed with atrazine, has shown good efficacy on a mixed spectrum of annual broadleaf and grass weeds when applied post-emergence to maize crops (Rahman et al. 2013). Saflufenacil is a new herbicide of the pyrimidinedione chemical class that acts by inhibiting the enzyme protoporphyrinogen IX oxidase (PPO) which in turn prevents chlorophyll biosynthesis (Grossmann et al. 2010). After application saflufenacil elicits rapid light-dependent wilting and necrosis of shoot tissue, as is common with the PPO inhibiting herbicides (Matringe et al. 1993). Its translocation is predominantly via the xylem and selectivity is conferred via both physical placement and plant tolerance (Grossmann et al. 2010; Liebl et al. 2008).

Topramezone is a selective post-emergence herbicide that belongs to the chemical class called pyrazolones. Its mode of action is to inhibit the enzyme 4-hydroxyphenylpyruvate dioxygenase (4-HPPD) and the biosynthesis of plastoquinone, with subsequent carotenoid pigment formation, membrane structure and chlorophyll disruption (Grossmann \& Ehrhardt 2007; Schonhammer et al. 2006). Plant damage is expressed in pronounced bleaching symptoms of the growing shoot tissue and subsequent necrosis of the above ground foliage. Its moderate water solubility and persistence in soil allows root as well as foliar uptake by plants. 
Past research has shown that the residual herbicides used for weed control in maize crops can sometimes persist in the soil at concentrations high enough to damage sensitive crops in the rotation (Rahman \& James 1994). As more maize is now grown for silage and harvested earlier than grain crops, the likelihood of damage to sensitive species is increased due to reduced time available for herbicide dissipation. Persistence of soil applied herbicides is known to vary considerably between different soil types as well as climatic regions. A large volume of published information is available in New Zealand showing that both the plant availability and residual activity of herbicides used in maize crops are strongly influenced by soil characteristics and environmental factors, such as the amount and timing of rainfall and soil temperature (Rahman \& James 1994, 1995, 2002). New Zealand soils have high organic matter levels compared to most other countries, are mostly acidic ( $\mathrm{pH}$ between 5.5 and 6.5) and many are derived from volcanic materials, with a high proportion of allophane clay (Burney et al. 1975; Rahman \& James 2002). It is important therefore to investigate the persistence of residual herbicides in the local maize cropping soils and climatic conditions.

The objective of this study was to assess the level of residual activity of two newly introduced residual herbicides for weed control in maize crops and to establish the safe plant-back periods for crops likely to follow in the rotation.

\section{MATERIALS AND METHODS}

\section{Field trials}

The field trial sites for both herbicides were located at the Research Farm of Ruakura Research Centre, Hamilton. The soil type for the saflufenacil study was a Te Rapa peaty silt loam with $9.9 \%$ organic $\mathrm{C}$, a $\mathrm{pH}$ of 6.0 , CEC of $38 \mathrm{me} / 100 \mathrm{~g}$ and bulk density of $0.56 \mathrm{~kg} / \mathrm{litre}$. For the topramezone study the soil type was a Te Kowhai silt loam with $6.0 \%$ organic C, a pH of 6.0 , CEC of $38 \mathrm{me} / 100 \mathrm{~g}$ and a bulk density of $0.76 \mathrm{~kg} /$ litre. Individual plots were set up as single strips of $3 \mathrm{~m} \times 20 \mathrm{~m}$ for each treatment. The treatments included untreated control, saflufenacil (BAS 800 04H, 348 g/litre SC; now registered as Sharpen, $700 \mathrm{~g} / \mathrm{kg}$ WSG) at 17 ,
51 and $102 \mathrm{~g}$ ai/ha and topramezone (Arietta, $336 \mathrm{~g} /$ litre SC) at 101 and $202 \mathrm{~g}$ ai/ha. The label rates for use in maize and sweet corn are 105 and $67.2 \mathrm{~g}$ ai/ha for saflufenacil and topramezone, respectively. For saflufenacil, the label rate for use in conservation tillage and pasture renovation is $17.5 \mathrm{~g}$ ai/ha. The rates used in the present experiments are different from the recommended rates because the label rates had not been determined at that stage. The adjuvant Hasten was added at $0.5 \% \mathrm{v} / \mathrm{v}$ to all herbicide treatments to simulate the field use situation.

The herbicide treatments were applied to freshly cultivated soil on 9 March 2010 for saflufenacil and 11 December 2011 for topramezone with a $\mathrm{CO}_{2}$ pressurised, hand-held sprayer fitted with a $3 \mathrm{~m}$ boom and four TeeJet flat-fan nozzles in a spray volume of 200 litres/ ha at $160 \mathrm{kPa}$. The average temperature for the period of the saflufenacil trial was $15.9^{\circ} \mathrm{C}$ (range $11.0-19.2^{\circ} \mathrm{C}$ ) and the total rainfall was $27.4 \mathrm{~mm}$, with the first rainfall occurring 2 weeks after treatment (WAT). The soil was mostly dry, with average soil moisture for the period being $21.5 \%$ (range $18.7-24.2 \%$ ). For the topramezone trial, the average temperature was $16.5^{\circ} \mathrm{C}$ (range $10.9-20.5^{\circ} \mathrm{C}$ ) and the total rainfall was $304 \mathrm{~mm}$, with $49 \mathrm{~mm}$ recorded during the first week after treatment. Thus the soil was moist, with average soil moisture for the period being $41.5 \%$ (range $32.6-52.0 \%)$.

\section{Soil sampling}

Soil samples for bioassay of herbicide residues were collected from different parts of each plot across the spray boom width. A flat spade was used to collect the soil from the top $5 \mathrm{~cm}$. Each strip was divided into four sections and four samples were collected from each section. Samples from each section were bulked and after thorough mixing in the glasshouse, the soil was used to plant three pots of each bioassay species listed below.

For saflufenacil, soil samples were collected from each plot the day after application and then at 1,2, 3 and 4 WAT. For topramezone, sampling times were 2, 4 and 8 WAT. The additional earlier sampling times for saflufenacil were included 
because it is also registered for use in conservation tillage and pasture renovation where crops could follow in rotation soon after its application.

\section{Glasshouse bioassay}

The test species used and the number of their seeds planted in each pot for bioassay of both herbicides were: wheat (Triticum aestivum cv. Einstein; 10 seeds), perennial ryegrass (Lolium perenne cv. Bronsyn; 20 seeds), squash (Cucurbita moschata cv. Delica Hybrid; 6 seeds), tomato (Solanum lycopersicum cv. Moneymaker; 6 seeds), carrot (Daucus carota cv. All Year Round; 20 seeds), onion (Allium cepa cv. Pukekohe Longkeeper; 20 seeds), radish (Raphanus sativus cv. French breakfast; 10 seeds), peas (Pisum sativum cv. Somerwood; 6 seeds) and white clover (Trifolium repens cv. Kopu II; 20 seeds). Seeds of each bioassay species were planted into $15-\mathrm{cm}$ diameter plastic pots, which were then placed in the glasshouse with a day/night temperature of $25 / 15^{\circ} \mathrm{C}$ and watered as required.

Assessments included timing of seedling emergence, number of seedlings emerged and visual scoring of damage symptoms at weekly intervals. The visual damage scores $(0-100$ scale) combined the effects on height and vigour compared to untreated control. After emergence the seedlings were thinned to five plants per pot for wheat, peas, radish, squash, tomato and onions and 10 plants each for the other species. After 4 weeks the plants were harvested for dry matter weight determination. All data were subjected to analysis of variance (ANOVA) to separate the means. The treatment arithmetic means and least significant difference (LSD) are presented in the tables.

\section{RESULTS}

\section{Saflufenacil}

In the case of wheat, no damage was observed in any treatment at any of the sampling dates as the seedlings all emerged normally and grew well. In the case of perennial ryegrass, damage was observed only in soil samples collected on Day 1 and only at the highest rate (102 g ai/ha). This damage was in the form of delayed emergence and stunted growth of plants (average damage score of $13 \%)$. These two species, therefore, appear to have very good tolerance to saflufenacil.
Damage to squash was confined only to the highest rate in samples collected 1 day after treatment (DAT) and 1 WAT (average scores of $20 \%$ ). It was expressed as delayed emergence and smaller plants with slightly paler colour. Damage to peas was limited to soil samples collected on Day 1 only at the two high rates (17\% and $27 \%$ at 51 and $102 \mathrm{~g}$ ai/ha, respectively) and was exhibited in the form of slightly delayed emergence, resulting in smaller plants. These plants recovered from the initial damage and no significant reduction occurred in the dry matter weights. Thus both squash and peas appear to have good tolerance to saflufenacil residues in the soil.

Bioassays with tomato plants showed herbicide damage at all three rates in samples collected on Day 1. This consisted of reduced height and vigour, with some plants showing purplish leaves (average scores of 27, 36 and $45 \%$ at 17, 51 and $102 \mathrm{~g}$ ai/ha rates, respectively). The reduced growth was reflected in their dry weights, with affected plants producing only 78,58 and $47 \%$ of dry matter compared to the untreated control. The residual activity had fallen to below phytotoxic levels by Day 7, suggesting that tomatoes are only moderately susceptible to saflufenacil.

The remaining four bioassay species, white clover, onion, carrot and radish, were more susceptible than the species mentioned above, showing phytotoxicity from residues of saflufenacil at all three rates (Table 1). At the lowest rate of $17 \mathrm{~g}$ ai/ha, significant damage was noted only in the first two samplings, i.e. up to 1 WAT. However, the damage was considerable at the two higher rates in samples collected up to 3 WAT. By 4 WAT, residual activity had fallen below phytotoxic levels in all treatments.

Damage to white clover appeared in the form of fewer emerged and shorter plants, smaller leaves and sometimes pale-coloured foliage. This resulted in reduced growth and vigour. For onions, delayed emergence and thinner seedlings were the common damage parameters. Damage to carrots was expressed as a reduced number of plants, delayed emergence, shorter plants, smaller leaves and curling of cotyledons. For radish, the damage consisted of fewer seedlings, reduced height and vigour, bluish green or yellow colour 
Table 1 Percent damage to bioassay species (compared to untreated $=0$ ) in soil samples collected at different times after spraying of saflufenacil.

\begin{tabular}{|c|c|c|c|c|c|c|}
\hline \multirow[b]{2}{*}{ Bioassay species } & \multirow{2}{*}{$\begin{array}{c}\text { Rate } \\
\text { (g ai/ha) }\end{array}$} & \multicolumn{5}{|c|}{ Soil samples collected at ${ }^{1}$} \\
\hline & & $1 \mathrm{DAT}$ & $1 \mathrm{WAT}$ & 2 WAT & 3 WAT & $4 \mathrm{WAT}$ \\
\hline \multirow{3}{*}{ White clover } & 17 & 15 & 23 & 10 & 10 & 0 \\
\hline & 51 & 67 & 40 & 27 & 13 & 0 \\
\hline & 102 & 80 & 53 & 40 & 18 & 10 \\
\hline \multirow[t]{3}{*}{ Onion } & 17 & 20 & 10 & 10 & 10 & 0 \\
\hline & 51 & 30 & 30 & 23 & 10 & 0 \\
\hline & 102 & 37 & 38 & 45 & 17 & 0 \\
\hline \multirow[t]{3}{*}{ Carrot } & 17 & 20 & 20 & 10 & 10 & 0 \\
\hline & 51 & 63 & 55 & 33 & 17 & 0 \\
\hline & 102 & 85 & 63 & 43 & 33 & 0 \\
\hline \multirow{3}{*}{ Radish } & 17 & 30 & 20 & 15 & 10 & 0 \\
\hline & 51 & 60 & 75 & 33 & 33 & 10 \\
\hline & 102 & 60 & 75 & 66 & 27 & 10 \\
\hline $\operatorname{LSD}(\mathrm{P}=0.05)$ & & 12.3 & 14.8 & 16.2 & 11.6 & - \\
\hline
\end{tabular}

${ }^{1}$ Soil samples collected from field at 1 day after treatment and 1, 2, 3 and 4 weeks after treatment.

of the foliage and sometimes deformed plants.

Data on dry weights for the four most susceptible species are presented in Table 2. Overall, these measurements support the visual damage assessments, but often show lower toxicity of residues, suggesting that plants recovered with time, especially at low damage levels.

\section{Topramezone}

Bioassay results of the first samples collected 2 WAT showed no visual damage to wheat, ryegrass, carrot, squash, onions and tomato plants at either herbicide rate. In addition, there were no significant differences in emergence or dry matter weights of all these species between herbicide treatments and the untreated. Thus the residual activity of topramezone in the soil 2 weeks after application was not sufficient to adversely affect the germination and growth of these five species. They all appeared to have good tolerance to residues of topramezone in the soil.

Bioassay results for the other three species, radish, peas and white clover, are presented in Table 3. Damage to radish consisted of a slower growth rate resulting in reduced height/vigour and sometimes a lighter green or slightly yellowish colour of the foliage. Radish plants were affected by residues only at the 2 WAT sampling, with no phytotoxicity apparent in samples collected 4 or 8 WAT. Damage to peas was confined mostly to soil samples collected 2 WAT, with only a few plants showing minor damage symptoms in samples collected 4 WAT. The damage was exhibited in the form of slightly delayed emergence, resulting in smaller plants, which were at times a slightly lighter green colour.

White clover plants were damaged the most by residues of topramezone, especially at the higher rate (202 $\mathrm{g}$ ai/ha). In samples collected 2 WAT, damage levels averaged $73 \%$ at the high rate, and dry weight of these plants was only $26 \%$ of the untreated control (Table 3). However, residues dissipated quickly, as damage scores in soil samples collected 4 WAT averaged only $17 \%$ at the high rate. Samples collected 8 WAT showed residues had fallen below phytotoxic levels at both rates. Damage to clovers appeared in the form of stunted plants, smaller leaves and sometimes pale-coloured foliage. The most common effect was reduced growth and vigour.

\section{DISCUSSION}

Of the species used for bioassay of saflufenacil, wheat and perennial ryegrass were the most tolerant, while white clover, onion, carrot and radish were among the most susceptible to this 
Table 2 Dry matter weight of plants (total for pot expressed as \% of untreated at 4 weeks after planting) grown in soil samples collected at different times after spraying of saflufenacil.

\begin{tabular}{lcccccc}
\hline $\begin{array}{l}\text { Bioassay } \\
\text { species }\end{array}$ & $\begin{array}{c}\text { Rate } \\
\text { (g ai/ha) }\end{array}$ & 1 DAT & 1 WAT & 2 WAT & 3 WAT & 4 WAT \\
\cline { 2 - 6 } White clover & 17 & 81 & 86 & 90 & 132 & 103 \\
& 51 & 37 & 61 & 76 & 101 & 108 \\
& 102 & 31 & 43 & 49 & 76 & 102 \\
Onion & 17 & 78 & 84 & 105 & 105 & 109 \\
& 51 & 69 & 83 & 89 & 116 & 106 \\
& 102 & 62 & 76 & 78 & 121 & 98 \\
Carrot & 17 & 80 & 71 & 92 & 91 & 118 \\
& 51 & 35 & 50 & 71 & 94 & 97 \\
& 102 & 27 & 43 & 67 & 72 & 98 \\
Radish & 17 & 80 & 96 & 128 & 95 & 110 \\
& 51 & 56 & 55 & 81 & 99 & 93 \\
& 102 & 41 & 45 & 58 & 78 & 91 \\
LSD (P =0.05) & & 13.4 & 15.9 & 16.8 & 15.2 & 11.6
\end{tabular}

${ }^{1}$ Soil samples collected from field at 1 day after treatment and 1, 2, 3 and 4 weeks after treatment.

herbicide. Squash, peas and tomatoes were only moderately susceptible.

Phytotoxic residues from the lowest rate of saflufenacil (17 $\mathrm{g}$ ai/ha), the rate recommended for conservation tillage and pasture renovation, persisted in the soil for $<2$ weeks, even for the most susceptible species likely to follow in the rotation. At the low use rate, Liebl et al. (2008) also reported adequate pre-plant safety and suggested that saflufenacil can be tank-mixed with glyphosate for effective burndown of emerged weeds in reduced and no-tillage cropping. Residual activity of the highest rate (102 $\mathrm{g}$ ai/ha), which is close to the recommended rate for maize, dissipated within
4 WAT for the most susceptible species. As saflufenacil is used pre-emergence in maize crops, this length of residual activity is unlikely to cause phytotoxic damage to crops following in the normal rotation, even in the case of silage crops. Other research has also shown minimal residual carryover to other crops when saflufenacil is used for selective weed control in maize (Soltani et al. 2009).

In the case of topramezone, wheat, ryegrass, carrot, squash, onion and tomato plants were not affected by its residues, even in samples collected 2 WAT. Peas, white clover and radish all suffered damage in soil samples collected 2 WAT, with

Table 3 Bioassay results (\% damage and dry matter as \% of untreated at 4 weeks after planting) for radish, peas and white clover at different sampling times after treatment with topramezone.

\begin{tabular}{|c|c|c|c|c|c|}
\hline \multirow{2}{*}{$\begin{array}{l}\text { Bioassay } \\
\text { species }\end{array}$} & \multirow{2}{*}{$\begin{array}{c}\text { Rate } \\
\text { (g ai/ha) }\end{array}$} & \multicolumn{2}{|c|}{$\%$ damage } & \multicolumn{2}{|c|}{ DM (\% of untreated) } \\
\hline & & $2 \mathrm{WAT}^{1}$ & $4 \mathrm{WAT}^{1}$ & $2 \mathrm{WAT}$ & 4 WAT \\
\hline Radish & $\begin{array}{l}101 \\
202\end{array}$ & $\begin{array}{l}10 \\
18\end{array}$ & $\begin{array}{l}0 \\
0\end{array}$ & $\begin{array}{l}92 \\
75\end{array}$ & $\begin{array}{l}92 \\
96\end{array}$ \\
\hline Peas & $\begin{array}{l}101 \\
202\end{array}$ & $\begin{array}{l}20 \\
34\end{array}$ & $\begin{array}{l}5 \\
7\end{array}$ & $\begin{array}{l}59 \\
45\end{array}$ & $\begin{array}{c}97 \\
116\end{array}$ \\
\hline White clover & $\begin{array}{l}101 \\
202\end{array}$ & $\begin{array}{l}22 \\
73\end{array}$ & $\begin{array}{l}12 \\
17\end{array}$ & $\begin{array}{l}48 \\
26\end{array}$ & $\begin{array}{l}85 \\
68\end{array}$ \\
\hline $\operatorname{LSD}(\mathrm{P}=0.05)$ & & 12.3 & 5.8 & 14.2 & 11.6 \\
\hline
\end{tabular}

${ }^{1}$ Soil samples collected from field at 2 and 4 weeks after spraying of herbicide treatments. 
white clover being the most susceptible. However, residues had dissipated substantially by 4 WAT, with only white clover and peas still exhibiting minor phytotoxicity. No damage was noted to any plants growing in soil samples collected 8 WAT. These results suggest that a plant-back period of 2 to 8 weeks should be sufficient depending on the species in the rotation. Topramezone has been reported to have moderate persistence in soil by Schonhammer et al. (2006) and Gorsic et al. (2008). Its average half-life based on four North American field trials was 14 days and the residues were confined mainly to the top layer of the soil (Anonymous 2007). As the rates used in the present study were 1.5 and 3 times the recommended rate and considering that topramezone would normally be used in maize before late December, it is unlikely to cause phytotoxic damage to crops following in rotation.

\section{ACKNOWLEDGEMENTS}

Financial support for this work was provided by BASF New Zealand Limited.

\section{REFERENCES}

Anonymous 2007. Impact herbicide: Technical Information and Use Guide. AMVAC Chemical Corporation, Los Angeles, California, USA.

Burney B, Rahman A, Oomen GAC, Whitham JM 1975. The organic matter status of some mineral soils in New Zealand. Proceedings of the 28th New Zealand Weed and Pest Control Conference: 101-103.

Gorsic M, Baric K, Galzina N, Scepanovic M, Ostojic Z 2008. Weed control in maize with new herbicide topramezone. Cereal Research Communications 36: 1627-1630.

Grossmann K., Ehrhardt T 2007. On the mechanism of action and selectivity of the maize herbicide topramezone; a new inhibitor of 4-hydroxyphenylpyruvate dioxygenase. Pest Management Science 63: 429-439.

Grossmann K, Niggeweg R, Christiansen N, Looser R, Ehrardt T 2010. The herbicide saflufenacil (Kixor) is a new inhibitor of protoporphyrinogen IX oxidase activity. Weed Science 58: 1-9.
Liebl R, Walter H, Bowe SJ, Holt TJ, Westberg DE 2008. BAS 800H: a new herbicide for preplant burndown and preemergence dicot weed control. Weed Science Society of America Conference. Abstract 120.

Matringe M, Camadro JM, Brouillet N 1993. Protoporphyrinogen oxidase, the molecular target site for peroxidizing herbicides. Proceedings of the Brighton Crop Protection Conference - Weeds: 703-711.

Rahman A, James TK 1994. Field persistence of some maize herbicides in two soils. Proceedings of the 47th New Zealand Plant Protection Conference: 6-10.

Rahman A, James TK 1995. Improving performance and reliability of soil applied herbicides in New Zealand. Proceedings of the 15th Asian-Pacific Weed Science Society Conference: $627-635$.

Rahman A, James TK 2002. Minimising environmental contamination by selecting appropriate herbicide dose. In: Kookana RS, Sadler R, Sethunathan N, Naidu R. ed. Environmental Protection and Risk Assessment of Organic Contaminants. Science Publishers Inc., Enfield, NH, USA. Pp. 209-224.

Rahman A, Trolove MR, James TK 2013. Efficacy and crop selectivity of topramezone for post-emergence weed control in maize. Proceedings of the 24th Asian-Pacific Weed Science Society Conference: 470-476.

Schonhammer A, Freeitag J, Koch H 2006. Topramezone - ein neuer Herbizidwirkstoff zur hoghselektiven Hirse - under Unkrautbekampfung in Mais. (Topramazone - a new highly selective herbicide compound for control of warm season grasses and dicotyledonous weeds in maize). Journal of Plant Diseases and Protection. Supplement 20. Pp. 1023-1031.

Soltani N, Shropshire C, Sikkema PH 2009. Response of corn to preemergence and postemergence applications of saflufenacil. Weed Technology 23: 331-334.

Trolove MR, Rahman A, Hagerty GC, James TK 2011. Efficacy and crop selectivity of saflufenacil alone and with partner herbicides for weed control in maize. New Zealand Plant Protection 60: 133-141.

Refer to http://www.nzpps.org/terms_of_use.htm/ 